\title{
PENTINGNYA ETIKA DALAM PENDIDIKAN
}

\author{
Rafsel Tas'adi \\ Program Studi Bimbingan Konseling, Jurusan Tarbiyah STAIN Batusangkar \\ Korespondensi: Jl. Sudirman, No.137 Kubu Rajo, Lima Kaum, Batusangkar, Sumatera Barat
}

\begin{abstract}
The depelopment of technology in Globalization era may give bad influence to education nowadays. It had created people's moral crisis, especially students. The changing of the students' mentality and moral, for example, might be happened because of internal and/or external factors. The students never feel upset after doing something bad to others. They seemed that they did not know of how to respect adult people when doing communication. And, there were some other problems among the students. It might happen because they got lack of education about etique both at school or outside the school. The education of etique was really needed to do in order to solve those problems. It was clear that it became important thing in educational system today. The progress of education in one country, especially in Indonesia, could be seen from the suceed of implementing education characters to its students. One of the possible thing of changing character was through giving education of etique to them.
\end{abstract}

Kata kunci: etika, pendidikan, guru, siswa

\section{PENDAHULUAN}

$\mathrm{P}$ endidikan merupakan salah satu aspek yang sangat penting untuk membentuk generasi yang siap mengganti tongkat estafet generasi tua dalam rangka membangun masa depan. Karena itu pendidikan berperan mensialisasikan kemampuan baru kepada mereka agar mampu mengantisipasi tuntutan masyarakat yang dinamis. Perubahan yang terjadi dengan begitu cepat tidak terlepas dari perkembangan teknologi dan ilmu pengetahuan, atau yang lebih dikenal dengan era globalisasi.

Perubahan yang terlihat mencolok pada era globalisasi dan terlihat sangat tajam adalah faktor percepatan. Ini disebabkan oleh kemajuan yang pesat dalam bidang teknologi informasi dan komunikasi, maupun kemajuan yan pesat dalam bidang transportasi khususnya penerbangan antar benua. Integritas perkembangan komunikasi dan teknologi informasi yang semakin cepat mengharuskan dunia pendidikan untuk mempersiapkan berbagai kebutuhan perangkat keras, perangkat lunak serta perangkat intelektual.

Globalisasi telah menciptakan dunia semakin terbuka dan saling ketergantungan antar bangsa dan antar negara. Bagi negara maju memang sangat menguntungkan karena mereka bertindak sebagai subjek tetapi bagi negara berkembang akan memberikan dampak yang yang merugikan sebab negara berkembang lebih cenderung sebagai sasaran atau objek globalisasi. Melihat kondisi yang seperti ini maka diperlukan antisipasi yang tepat dari negara berkembang khususnya negara Indonesia salah satunya melalui dunia pendidikan. 
Tantangan yang menghadang dunia pendidikan Indonesia saat ini meliputi: heterogenitas tingkat pendidikan masyarakat, keterpurukan perekonomian masyarakat, kekurangmerataan tingkat pendidikan pendidikan, serta mulai lunturnya nilai-nilai moral. Heterogenitas tingkat pendidikan masyarakat Indonesia dapat dilihat pada masyarakat diseluruh kepulauan Indonesia. Masih banyak penduduk yang buta aksara terutama di pedesaan, di samping mayoritas sudah dapat membaca dan menulis bahkan banyak yang sarjana.

Pada jenjang sekolah dasar, terutama di pedesaan banyak anak-anak usia sekolah yang tidak pernah mengikuti sekolah dasar, putus sekolah, di samping banyak yang tamat sekolah dasar. Hal yang sama juga terjadi pada jenjang pendidikan SLTP dan SLTA. Penyebab utamanya adalah masalah kemiskinan dan ketidakmampuan orang tua menyekolahkan anaknya ke jenjang pendidikan yang lebih tinggi. Berdasarkan uraian di atas dapat disimpulkan bahwa kesempatan untuk mengikuti pendidikan formal dan berbagai pelatihan keterampilan teknis bagi anak-anak (pemuda) sangat terbatas, jumlah pemuda putus sekolah meningkat, bahkan banyak yang tidak pernah sekolah, jumlah pemuda melek huruf fungsional sangat rendah, dan mutu SDM generasi muda sangat buruk.

Berbicara tentang pendidikan, dapat bermakna sangat luas, "dalam pengertian maha luas, pendidikan sama dengan hidup. Pendidikan adalah segala situasi dalam hidup ya ng mempengaruhi pertumbuhan seseorang. Pendidikan adalah pengalaman belajar. Oleh karena itu, pendidikan dapat pula didefinisikan sebagai keseluruhan pengalaman belajar setiap orang sepanjang hidupnya. Dalam pengertian yang maha luas, pendidikan berlangsung tidak dalam batas usia tertentu, tetapi berlangsung sepanjang hidup (lifelong) sejak lahir (bahkan sejak awal hidup dalam kandungan) hingga mati. Selain itu, dalam pengertian maha luas, tempat berlangsungnya pendidikan tidak terbatas dalam satu jenis lingkungan hidup tertentu dalam bentuk sekolah, tetapi berlangsung dalam segala bentuk lingkungan hidup manusia" (Redja Mudyahardjo: 2008:46).

Dari makna pendidikan dalam konteks sangat luas itu, menujukkan bahwa pendidikan itu adalah kebutuhan manusia untuk mendapatkan hidup yaag bermakna dan berkualitas, hal ini dapat kita pahami dari tujuan pedidikan yang tertera dalam UU Sisdiknas No. 20 tahun 2003 Bab II Pasal 3 dinyatakan "Pendidikan nasional berfungsi mengembangkan kemampuan dan membentuk watak serta peradaban bangsa yang bermartabat dalam rangka mencerdaskan kehidupan bangsa, bertujuan untuk berkembangnya potensi pserta didik agar menjadi manusia yang beriman dan bertaqwa kepada Tuhan yang maha Esa. Berakhlak, sehat, berimu, cakap, kreatif, mandiri, dan menjadi warga negara yang demokratis dan bertanggung jawab.

Untuk terwujudnya tujuan pendidikan ini tentu banyak hal yang perlu diperhatihatikan baik pada diri si pendidik maupun siterdidik. Salah satu hal yang perlu diperhatikan dalam proses pendidikan ini adalah masalah etika. Kondisi hari ini yang terjadi dalam dunia pendidikan sungguh memprihatinkan kita semua. Banyak hal yang terjadi yang membuat resah diri kita, membuat kita bersedih, menangis, resah. Kita tau jika anak-anak kita di sekolah adalah aset bangsa, namun kenapa masih terjadi juga hal-hal yan tidak kita inginkan dalam duia pendidikan.

"Berbagai realitas di masyarakat membuktikan pendidikan belum mampu menghasilkan anak didik berkualitas secara keseluruhan. Kenyataan ini dapat dicermati dengan banyaknya perilaku tidak terpuji terjadi di masyarakat, sebagai contoh merebaknya penggunaan 
narkoba, penyalahgunaan wewenang, korupsi, manipulasi, perampokan, pembunuhan, pelecehan seksual, pelanggaran hak-hak azasi manusia, pengniayaan, Realitas ini memunculkan anggapan bahwa pendidikan belum mampu membentuk anak didik berkepribadian paripurna. Pendidikan diposisikan sebagai institusi yang dianggap gagal membentuk anak didik beretika baik dan mulia" (Istighfarotur Rahmaniyah: 2009: $3)$.

Berbagai bentuk pelanggaran etika ini tidak hanya dilakukan oleh anak-anak pada jenjang pendidikan yang tinggi saja. Baru-baru ini banyak berita yang kita dengar dari media massa kalau pelanggaran etika ini dilakukan oleh anak-anak di tingkat dasar. Ada kakak kelas yang menganiaya adik kelas, ada yang hanya masalah sepele tidak sengaja menjatuhkan makanan teman, lalu memukul temannya. Realitas seperti ini betul-betul budaya kemanusiaannya sudah hilang. Rasa sosial, rasa mengasihi, toleransi, tolong-menolong antar sesama sudah jauh pada diri anak-anak kita. Pada hal kejadian itu terjadi di lingkungan sekolah. Di sana ada guru, teman, namun lingkungan itupun tidak banyak berbuat.

Kondisi buruk yang juga sering kita saksikan terjadi dilingkungan para pelajar dan mahasiswa seringnya terjadi tawuran, yang sampai menelan korban. Justru yang aneh pihak yang menang merasa bangga melihat temannya sesama pelajar, sesama satu sekolah, sesama bangsa. Aneh sungguh sangat aneh. Memang tidak mudah untuk menemukan apa yang menyebabkan semua ini. Faktor apakah sebenarnya yang menyebabkan semua ini?. Tentu tidak dapat disalahkan satu pihak saja, yang pasti anak akan belajar dari lingkungannya. Oleh karena itu hendaknya semuga lingkungan hendaknya memperhatikan perlunya Etika untuk semua lingkungan pendidikan.

\section{PERMASALAHAN}

Sebagaimana yang telah dijelaskan pada latar belakang masalah di atas, bahwa berbagai bentuk perilaku siswa yang dinilai bertentangan dengan etika sudah banyak terjadi, penyimpangan baik dari diri siswa maupun guru. Sepertinya persoalan ini bukan makin lama makin berkurang, bahkan terkesan semakin meresahkan. Sejak beberapa tahun terakhir ini kita merasakan bahwa mulai banyak norma-norma tata krama yang dilanggar. Norma yang paling dasar saja yakni menyapa guru sudah mulai ditinggalkan. Dalam komunikasi verbal sudah tampil kata-kata jorok, yang sudah barang tentu tidak kita asosiasi dengan orang terpelajar. Sesama teman suka tidak peduli, mudah emosi, dll. Semua dapat kita nilai sebagai suatu gejala perubahan sosial budaya yang membawa perubahan tata nilai. Kita harus mencegah situasi tersebut sampai ke akarnya.

\section{PEMBAHASAN}

\section{Makna Etika}

Pengertian etika sering disamakan dengan pengertian akhlak dan moral dan ada pula ulama yang mengatakan bahwa akhlak merupakan etika Islam. Di dalam buku kamus Istilah Pendidikan dan Umum dinyatakan bahwa etika adalah bagian filsafat yang mengajarkan tentang keluhuran budi (baik buruk). (Istighfarotur Rahmaniyah: 2009: 57)

Istilah etika berasal dari kata latin: Ethic (us), dalam bahasa Gerik: Ethikos $=a$ body of moral principles or values Ethic $=$ arti sebenarnya, ialah kebiasaan, habit, costum. Jadi dalam pengertian 
aslinya, apa yang disebutkan baik itu ialah yang sesuai dengan kebiasaan masyarakat (dewasa itu). Lambat laun pengertian etika itu berubah, seperti pengertian sekarang: Etika ialah suatu ilmu yang membicarakan masalah perbuatan atau tingkah laku manusia, mana yang dapat dinilai baik dan mana yang jahat". (Burhanudin Salam:3)

Dalam dunia pendidikan, tentu saja semua orang yang berada dalam lingkungan pendidikan tertentu harus terlebih dahulu memiliki etika. Jika pendidikan yang dimaksudkan di institusi secara formal, maka Guru, siswa, dan semua personil lainnya harus memiliki etika yang baik dalam bertingkah laku sehari-hari. Contoh-contoh perilaku yang nyata sangat mempengaruhi suasana di lingkungan sekolah. Bagaimana seorang anak menyapa guru, Guru menegur siswa, bgaimana seorang anak yang satu berkomunikasi dengan anak lainnya, semua harus sesuai dengan norma yang berlaku. Jika semua tingkah laku yang terjadi sudah lari dari etika, maka bermunculanlah berbagai macam persoalan.

Seharusnya setiap orang mampu membedakan mana yang baik, mana yang buruk, mana yang pantas untuk dilakukan, dan mana yang harus ditinggalkan untuk tidak dilakukan. "Individu yang matang secara moral tidak akan membiarkan masyarakat untuk mendikte mereka karena mereka tidak mengharapkan hadiah atau hukuman yang berwujud ketika memenuhi atau tidak memenuhi standar moral". (Aliah B. Purwakania Hasan: 2006: 261).

Moralitas memiliki tiga komponen, yaitu komponen afektif, kognitif dan perilaku. Komponen afektif atau emosional terdiri dari berbagai jenis perasaan (seperti perasaan bersalah atau malu), perhatian terhadap perasaan orang lain, dan sebagainya) yang meliputi tindakan benar dan salah yang memotivasi pemikiran dan tindakan moral. Komponen kognitif merupakan pusat di mana se- seorang melakukan konseptualisasi benar dan salah dan membuat keputusan tentang bagaimana seseorang berperilaku. Komponen perilaku mencerminkan bagaimana seseorang sesungguhnya berperilakau. Komponen perilaku mencerminkan bagaimana seseorang sesungguhnya berperilaku ketika mengalami godaan untuk berbohong, curang atau melanggar aturan moral lainnya. (Aliah B. Purwakania Hasan: 2006: 261). Setiap individu hendaknya memiliki kecerdasan moral/etika, dalam setiap perilakunya.

Berikutnya, etika dinyatakan sebagai filsafat moral, yaitu studi yang sistematik mengenai sifat dasar dari konsep-konsep nilai baik, buruk, harus, benar, salah, dan sebagainya. Sementara itu, etika dikelompokkan menjadi dua definisi:

a. Etika merupakan karakter individu Dalam hal ini termasuk bahwa orang yang beretika adalah orang yang baik. Pengertian ini disebut pemahaman manusia sebagai individu yang beretika. Etika merupakan hukum sosial.

b. Etika merupakan hukum

Etika yang mengatur, mengendalikan serta membatasi perilaku manusia.

Dalam hubungan ini Dr. $\mathrm{H}$. Hamzah Ya'qub menyimpulkan bahwa etika adalah ilmu yang menyelidiki manayang baik dan mana yang buruk dengan memperhatikan amal perbuatan manusia sejauh yang dapat diketahui oleh akal pikiran. (Hamzah Ya'qub, 1991: 13) .Demikianlah, etika akhirnya merupakan ilmu pengetahuan rohaniah, normatif, teologis. Etika bukan lagi ilmu pengetahuan yang dapat diukur secara matematis. Karenanya tidak dapat diramalkan dengan pasti. Etika lebih merupakan pengetahuan tentang kepandaian atau seni hidup secara baik (the art of good living). Dari definisi etika tersebut di atas, dapat segera diketahui bahwa etika berhubungan dengan empat hal sebagai berikut: 
a. Dillihat dari segi objek pembahahasannya Etika berupaya membahas perbuatan dilakuakan oleh manusia.

b. Dilihat dari segi sumbernya Etika bersumber pada akal pikiran atau filsafat. Sebagai terbatas, dapat berubah, memiliki kekurangan, kelebihan dan sebagainya. Selain itu juga memanfaatkan berbagai ilmu yang membahas perilaku manusia seperti ilmu antropologi, psikologi, sosiologi, ilmu politik, ilmu ekonomi dan sebagainya.

c. Dilihat dari segi fungsinya Etika berfungsi sebagai penilai, penentu dan penetap terhadap seuatu perbuatan yang dilakukan oleh manusia, yaitu apakah perbuatan tersebut akan dinilai baik, buruk, mulia, terhormat, hina dan sebagainya. Dengan demikian etika tersebut berperan sebagai konseptor terhadap sejumlah perilaku yang dilaksanakan oleh manusia. Etika lebih mengacu kepada pengkajian sistem nilai-nilai yang ada.

d. Dilihat dari segi sifatnya Etika bersifat relatif yakni dapat berubah-ubah sesuai dengan tuntutan zaman.

Dengan ciri-cirinya yang demikian itu, maka etika lebih merupakan ilmu pengetahuan yang berhubungan dengan upaya menentukan perbuatan yang dilakukan manusia untuk dikatakan baik dan buruk. Berbagai pemikiran yang dikemukakan filosof barat mengenai perbuatan baik dan buruk dapat dikelompokkan kepada pemikiran etika, karena berasal dari hasil berfikir.Dengan demikian etika sifatnya humanisstis dan antroposentrid yakni pada pemikiran manusia dan diarahkan pada manusia. Dengan kata lain etika aturan atau pola tingkah laku yang dihasilkan oleh akal manusia.

\section{Obyek Etika}

Nilai etika dan begitu juga untuk setiap nilai, adalah hasil kegiatan rohani, yakni akal dan perasaan. Perasaan memberikan bahan-bahannya, akal mengolah bahan tersebut yang diterimanya. Rasa nilai ini bisa dikerdilkan, diperkembangkan maupun dipunahkan. Semakin rumit putusan yang dihadapi perasaan, semakin luas lapangan kerja akal, namun sebaliknya semakin kecil peranan yang dipegangnya. Dikatakan semakin luas lapangan kerjanya, oleh karena akal dalam menghadapi keputusan yang muskil itu harus meneliti menganalisa, membanding-bandingkan dan mengatur halhal yang bersangkut paut dengan masalah pertama. (Mudlor Ahmad, t.th: 20).

\section{Tujuan Etika}

Tujuan adalah sesuatu yang dikehendaki, baik individu maupun kelompok. "Tujuan etika yang dimaksud merupakan merupakan tujuan akhir dari setiap aktivitas manusia dalam hidup dan kehidupannya yaitu untuk mewujudkan kebahagiaan. Tujuan utama etika yaitu menemukan, menentukan, membatasi, dan membenarkan kewajiban, hak, citacita moral dari individu dan masyarakatnya, baik masyarakat pada umumnya, khususnya masyarakat profesi”. (Istighfarotur Rahmaniyah, 2009: 62)

\section{Fungsi Etika}

Etika berfungsi sebagai penilai, penentu dan penetap terhadap seuatu perbuatan yang dilakukan oleh manusia, yaitu apakah perbuatan tersebut akan dinilai baik, buruk, mulia, terhormat, hina dan sebagainya. Dengan demikian etika tersebut berperan sebagai konseptor terhadap sejumlah perilaku yang 
dilaksanakan oleh manusia. Etika lebih mengacu kepada pengkajian sistem nilainilai yang ada.

"I Gede A.B. Wiranata dalam bukunya menuliskan beberapa pendapat para ahli tentang fungsi etika, di antaranya adalah Rohaniawan Franz Magnis-Suseno, ia menyatakan bahwa etika berfungsi untuk membantu manusia mencari orientasi secara kritis dalam berhadapan dengan moralitas yang membingungkan" (Istighfarotur Rahmaniyah, 2009:64

\section{Macam-macam Etika}

a. Etika Deskriptif

Etika yang menelaah secara kritis dan rasional tentang sikap dan perilaku manusia, serta apa yang dikejar oleh setiap orang dalam hidupnya sebagai sesuatu yang bernilai. Artinya Etika deskriptif tersebut berbicara mengenai fakta secara apa adanya, yakni mengenai nilai dan perilaku manusia sebagai suatu fakta yang terkait dengan situasi dan realitas yang membudaya. Dapat disimpulkan bahwa tentang kenyataan dalam penghayatan nilai atau tanpa nilai dalam suatu masyarakat yang dikaitkan dengan kondisi tertentu memungkinkan manusia dapat bertindak secara etis.

\section{b. Etika Normatif}

Etika yang menetapkan berbagai sikap dan perilaku yang ideal dan seharusnya dimiliki oleh manusia atau apa yang seharusnya dijalankan oleh manusia dan tindakan apa yang bernilai dalam hidup ini. Jadi Etika Normatif merupakan norma-norma yang dapat menuntun agar manusia bertindak secara baik dan menghindarkan hal-hal yang buruk, sesuai dengan kaidah atau norma yang disepakati dan berlaku di masyarakat.

Dari berbagai pembahasan definisi tentang etika tersebut di atas dapat diklasifikasikan menjadi tiga (3) jenis definisi, yaitu sebagai berikut:- Jenis pertama, etika dipandang sebagai cabang filsafat yang khusus membicarakan tentang nilai baik dan buruk dari perilaku manusia.- Jenis kedua, etika dipandang sebagai ilmu pengetahuan yang membicarakan baik buruknya perilaku manusia dalam kehidupan bersama. Definisi tersebut tidak melihat kenyataan bahwa ada keragaman norma, karena adanya ketidaksamaan waktu dan tempat, akhirnya etika menjadi ilmu yang deskriptif dan lebih bersifat sosiologik. Jenis ketiga, etika dipandang sebagai ilmu pengetahuan yang bersifat normatif, dan evaluatif yang hanya memberikan nilai baik buruknya terhadap perilaku manusia. Dalam hal ini tidak perlu menunjukkan adanya fakta, cukup informasi, menganjurkan dan merefleksikan. Definisi etika ini lebih bersifat informatif, direktif dan reflektif. (Keraf: 1991: 23),

\section{ETIKA DALAM PENDIDIKAN}

Proses intemalisasi etika dalarn diri siswa tidak dapat dilakukan secara instant, namun melalui proses sejalan dengan perkembangan jasarnani dan rohani siswa. Proses intemalisasi dimulai dengan pengenalan nilai-nilai di dalam keluarga oleh orangtua maupun sanak famili yang serumah.Jika anak sudah bergaul dengan lingkungan sosialmasyarakat sekitar ia akan berkenalan dengan berbagai nilai disekitarnya. Dan jika ia sudah bersekolah pengenalan nilai akan sernakin banyak dan beragam yang dibawa oleh ternan-ternan sekolah, guru dan juga orang lain yanghadir di sekolah. Jika ia sudah mulai tertarik nonton televisi, rnaka ia juga akan berkenalan dengan nilai yang ditawarkan dan disampaikan oleh para artis-selebritis melalui adegan-adegan yang dibawakannya, selain lewat promosi atau iklan yangditayangkan. Nilai-nilai yang diterima siswa ada yang berbeda bahkan 
bertolak belakang atau berlawanan dengan nilai-nilai yang dikenalkan di rumah dandisekolah, ada nilai baru yang tidak belum dikenal di rurnah dan atau di sekolah.Terhadap rnasuknya nilai tersebut mungkin diterima melalui saringan atau filter orangtua dan atau lewat guru, tetapi juga ada nilai yang diterirna tanpa ilter.

Pertentangan nilai dalarn diri siswa dapat terjadi, yang dapat menyebabkan siswa memiliki standar ganda. Misal jika di rumah dan di sekoklah siswa kelihatan alim, sopan, baik dan takwa. Tetapi di luar, jika sudah bergabung dengan kelornpok gengnya mereka akan berperilaku yang sangat berbeda. Misal minum minuman beralkohol tinggi sampai mabuk, pesta gandalnarkoba bahkan pesta seks. Oalam surat kabar sering diberitakan penggerebekan yang dilakukan polisi terhadap rumah kos di mana pesta mabuk-mabukan, narkoba dan seks terjadi, dan ternyatapelakunya mahasiswa dan atau siswa.

Bagaimana perkembangan moral teljadi? Salah satu teori yang terkenal adalah yang dikemukakan oleh Lawrence Kohlberg. Kohlberg mengurutkan perkembangan menjadi tiga tahap, dan setiap tahap ada dua peringkat. Susunan peringkat itu, sebagai berikut: Tahap pertama: Prekonvensional. Oalam tahap ini ada dua peringkat yang dilalui, yaitu orientasi ketaatan dan sanksi. Orangtua mengajarkan mana perbuatan baik dantidak baik Jika anaka berbuat baik, orangtua memberikan ganjaran, penghargaan atau hadiah, tetapi jika anak melakukan perbuatan tidak baik, orangtua memberikansanksi hukuman. Anak akan belajar untuk melakukan perbuatan yang baik dan tidak lagi melakukan perbuatan yang tidak baik.

Peringkat kedua,berorientasi pada azas dan alat atau instrumentasi. Si anak belajar bahwa jika ia melakukan perbuatan baik, berarti ia melakukan sesuatu yang dapat diterima oleh lingkungannya dan tidak mendapatkan hukuman.Pada peringkat ini anak belajar memahami azas nilai baik dan azas itu merupakan instrumen untuk melakukan perbuatan yang dpat diterima oleh linngkungannya. Contoh cara meminta sesuatu secara sopan kepada orangtua dan orang lain.Misal kata: "bolehkan saya minta tolong...", "Anak tidak diajari untuk berkata: "He, kamu bantu saya", jika meminta bantuan dari orang lain karena kata itu tidak sopan.

Tahap kedua: Peringkat Konvensional. Nilai-nilai yang menjadi alasan untuk berbuat baik diterima sebagai nilianya untuk memenuhi kehendak orangtua sertalingkungannya. Dengan cara itu ia dapat diterima di dalam kehidupan bermasyarakat. Anak menyadari bahwa ia berada dalam suatu lingkungan sosial buadaya masyarakat yang memiliki tata nilai, aturan serta adat yang mengatur perilaku warga atau pendukungnya. Contoh para calon anggota DPR, Kepala Daerah atau Bupati diminta menandatangai suatu kontrak sosial oleh pendukungnya atau warga masyarakat yang tidak atau kurang percaya pada janji.

Mahasiswa meminta calon Rektor Universitas untuk menendatangani kontrak sosial yang diajukan mahasiswa. Terhadap hal ini ada yang mau tetapi ada pula yang menolak karena dinilai tidak sejalan dengan nilainya. Sedangkan peringkat keenam berpegang pada prinsip nilai etika yang berlaku universal. Misal prinsip keadilan, hak azasi manusia, demokrasi, persamaan jender dllnya prinsip-prinsip tersebut diterima dan dilaksanakan di dalam berkehidupan bersama. Atas dasar teori perkembangan etika Kohlberg tersebut, maka pen- 
didikan etika harus dimulai sejak dini dan berkesinambungan.

Apa yang telah ditanamkan di dalam keluarga tidak dihancurkan di sekolah, tetapi justru di sekolah anak diajari untuk memahami secara rasional alasannya (membangun moral reasoning). Hukuman secara fisik maupun kata-kata verbal yang menyakitkan hati dan perasaan yang diistilahkan "bullying" harns sudah ditinggalkan oleh guru dan siswa di dalam lingkungan sekolah.Kebiasaan memper olok-olok, mengejek, mempermalukan, menyoraki jika ada siswa yang dianggap aneh, dan juga kebiasaan mengeluarkan kata-kata yang bersifat negatif atau meremehkan (verbal discouragement) harus ditinggalkan.

Sebagai contoh ada guru yang mempunyai kebiasaan mengatakan siswanya sebagai wedus-wedus,berfikir lambat seperti keong bekicot, otak kebo, otak udang, goblok dan lain sebagainya. Secara psikologis kata-kata yang sifatnya menegatif dan meremehkan tersebut akan melukai , menggores hati siswa dan akan erdampak dalam perkembangan anak khususnya pada anak yang perasa dan sensitif terhadap kata-kata kasar (sarkasme).

Sekolah sebenamya mempunyai kewajiban untuk memperluas, memeperdalam pemahaman nilai-nilai yang diperlukan di dalam kehidupan bermsayarakat seperti; pengenalan etika profesi, etika bisnis, etika berlalu lintas, etika pergaulan, etika berbicara lewat telepon, etika moral dan lain sebagainya. Konflik nilai yang dialami dalam diri siswa antara nilai yang ditanamkan di dalam keluarga, sekolah dan adanya pengaruh dari lingkungan dapat menimbulkan kebingunan bahkan dapat membentuk kepribadian rangkap.

Perilaku di rumah dan di sekolah baik, alim, patuh dan sopan, tetapi jika di luar lingkungan rumah dan sekolah berbalik 180 derajad. Orangtua dan guru kaget ketika si anak ditangkap polisi karena pesta narkoba dan seks bersama teman-temanya di tempat penginapan. Jika tidak ada kesinambungan dalam pendidikan etika di sekolah anak akan mencari nilainya sendiri tanpa merasa perlu memehami alasannya dan menganggap nilai yang diambil dari lingkungan pergaulan serta media masa adalah baik, modern dan gauI.

Oleh karena itu sekolah wajib mengembalikan nuansa pendidikan etika di dalam proses pendidikan yang diselenggarakan oleh sekolah. Guru perlu mendidik dengan hati yang dilandasi kasih sayang kepada anak yang sedang tumbuh-kembang baik secara fisik maupun psikologik. Hubungan yang sifatnya hierarki-birokrasi, di mana guru merasa berkuasa atas murid yang selalu siap menghukum karena siswa dianggap salah, tidak mematuhi kata perintah guru harus diganti dengan hubungan pendampingan dalam perjalanan siswa menghayati proses pendidikan di sekolah.

Sekolah hendaknya bukan lagi sebagai penjara yang menakutkan bagi siswa yang akan belajar, tetapi memerdekakan. Sekolah sebagai tempat untuk menumbuh kembangkan kreativitas, daya imaginasi dan inovasi, menyenangkan, menentramkan hati dan tempat di mana siswa memperoleh pelayanan dalam perkembangan etika moral, watak kepribadian dan intelektualnnya.Guru bukan lagi sebagai sosok yang serba tahu, wajah angker tanpa senyum dan menakutkan karena kuasa atas siswa, tetapi sebagai pendamping yang selalu siap dan ramah mendampingi.

(https://www.google.co.id/?gws_rd=ssl\# $q=$ pelanggaran+etika + dalam + pendidik an+pdf) (Dinamika Pendidikan No. 11Th.XIV / Mei 2007 :19-22)

Dalam bukunya M. Alaika Salamullah berpendapat setidaknya ada dua langkah yang perlu ditempuh murid 
untuk menemukan guru ideal: 1. Hendaknya ia meminta pendapat kepada kalangan yang dipercaya tentang orang yang layak dijadikan guru.kalau perlu, ia bisa bertanya kepada orang-orang yang lebih berpengalaman dalam berguru. 2 . Mengamati secara langsung keadaan calon guru. Langkah yang kedua ini memang lebih berat, tapi akan membuat dirirnya lebih puas, karena ia tahu betul keadaan orang yang akan diangkatnya sebagai guru baik dari segi keilmuan maupun ketakwaannya. (Salamullah, 2008: 128).

\section{TUJUAN ETIKA MURID TER- HADAP GURU}

Ada empat tujuan dari etika murid terhadap guru. Dalam dunia pendidikan sudah dapat kita lihat. Bahwa etika mau menyediakan orientasi. Meskipun tidak setiap murid memerlukan orientasi itu apalagi tanpa etika ilmiah pun kebanyakan murid dengan sendirinya sedikit beretika, namun seorang murid yang tidak begitu saja mempercayakan diri pada pandangan lingkungan moral. Dalam penjelasan kitab Ta'lim Muta'al limada sekurang-kurang empat alasan tujuan etika murid terhadap guru yaitu:

a. Guru membimbing murid untuk menjadikan murid agar menjadi murid yang lebih baik dan sopan terhadap guru.

b. Guru membimbing murid untuk menjadikan murid agar lebih menghormati dan menghargai guru.

c. Guru membimbing jiwa murid agar menjadi manusia sejati, yang manusia mengerti bahwa dirinya adalah hamba Allah SWT

d. Guru membimbing jiwa murid agar melawati jalan-jalan menuju ridho Allah SWT.

\section{PENUTUP}

Berbicara tentang persoalan etika dalam dunia pendidikan di antaranya yang terkait hubungan guru dan murid, murid dengan murid atau murid dengan anggota masyarakat lainnya. Di sini guru sebagai elemen terpenting dalam pembelajaran, oleh arena itu guru harus dihormati. Tidak hanya etika terhadap guru saja yang perlu di perhatikan peserta didik, tapi juga etika dengan siswa yang lainnya dalam bergaul.

Etika sebenarnya memiliki cakupan yang sangat luas di dalam segenap sikap dan tingkah laku dalam berinteraksi dengan lingkungan. Siapapun yang menghendaki anaknya menjadi seorang yang berakhlak/beretika, maka hendaklah ia memelihara, menghormati, rendah hati, dalam setiap tindakan. Etika yang dimiliki seseorang akan dapat meningkatkan harga diri seseorang. Begitupun sebaliknya ketika seorang anak lari dari etika, secara sosial anak ini dalam lingkungannya akan bermasalah. Mungkin dia akan dikucilkan. Nah, beranjak dari kondisi ini semua maka etika menjadi sesuatu yang penting ada dalam sistem pendidikan kita.

\section{Saran}

Dengan begitu besar manfaat dan peranan rendah hati, taat, hormat, patuh, beretika terhadap guru (orang yang berilmu), maka kami kami menyarankan sebagai berikut:

1. Sebagai umat Islam yang beriman dan bertakwa kepada Allah SWT, seharusnya kita selalu berpegang teguh pada Al-Qur'an dan AlHadits, yang merupakan pedoman dalam kehidupan sehari-hari sehingga dengan harapan perilaku kita tidak bertentangan dengan ajaran Islam.

2. Agar ilmu menjadi berkah, manfaat baik untuk diri pribadi, maupun dimasyarakat nantinya maka dalam 
menuntut ilmu hendaknya memuliakan guru, taat, patuh, sopan dan santun terhadap guru (orang yang memberi ilmu).

3. Bahwa yang namanya guru, orang alim harus dihormati, ditaati, dipatuhi, dan jangan sampai membuat

\section{DAFTAR RUJUKAN}

Aliah B. Purwakania Hasan: 2006. Psikologi perkembangan Islam. PT Raja Grafindo Persada

Achmad, Mudlor. t.th. Etika Dalam Islam. Surabaya: Al-Ikhlas.

Burhanudin Salam. Etika Individual. Pola Dasar Filsafat Moral. Rineka Cipta

Istighfarotur Rahmaniyah. 2009. Pendidikan Etika. Aditya Media. Malang

Keraf, A. Sonny. 1991. Etika Bisnis Membangun Citra Bisnis Sebagai Profesi Luhur. Jakarta: Kanisius sakit hatinya. Sebagai seorang murid haruslah mempunyai etika yang sopan, dan dapat memuliakan guru guru, pada guru yang tidak zalim, dan jugaa siswa.

Mujtahid. 2009. Pengembangan Profesi Guru. Malang: UIN-Malang Press (Anggota IKAPI)

Purwanto, Ngalim. 2007. Ilmu Pendidikan Teoritis dan Praktis. Bandung: Remaja Rosda Karya.

Redja Mudyahardjo. 2008. Filsafat Ilmu Pendidikan. PT Bandung

Salamullah, Alaika M. 2008. Akhlak Hubungan Vertikal. Yogyakarta: Pustaka Insan Madani.

https://www.google.co.id/?gws_rd=ssl\#q =pelanggaran+etika+dalam + pen didikan+pdf (Dinamika Pendidikan No. 11Th.XIV / Mei 2007 :19-22) 